\title{
THREE DIMENSIONAL PARAMETRIC ANALYSES ON EFFECT OF FIBRE ORIENTATION FOR STRESS CONCENTRATION FACTOR IN FIBROUS COMPOSITE CANTILEVER PLATE WITH CENTRAL CIRCULAR HOLE UNDER TRANSVERSE LOADING
}

\author{
MOON BANERJEE ${ }^{1}$, N.K. JAIN ${ }^{1}$ AND S. SANYAL ${ }^{2}$ \\ ${ }^{1}$ Department of Applied Mechanics, National Institute of Technology, Raipur, \\ Chattisgarh 492010, India. \\ ${ }^{2}$ Department of Mechanical Engineering, National Institute of Technology, Raipur, \\ Chattisgarh 492010, India. \\ moonbanerjee@gmail.com; nkjmanit@rediffmail.com; \\ shubhashissanyal@rediffmail.com
}

\begin{abstract}
A number of analytical and numerical techniques are available for the two dimensional study of stress concentration around the hole(s) in isotropic and composite plates subjected to in-plane or transverse loading conditions. The information on the techniques for three dimensional analyses of stress concentration factor (SCF) around the hole in isotropic and composite plates subjected to transverse loading conditions is, however, limited. The present work emphasizes on the effect of fibre orientation (q) on the stress concentration factor in fibrous composite plates with central circular hole under transverse static loading condition. The work is carried out for cantilever fibrous composite plates. The effects of thickness -to- width (T/A) and diameter-to-width (D/A) ratios upon SCF at different fibre orientation are studied. Plates of four different composite materials were considered for hole analysis in order to determine the sensitivity of SCF with elastic constants. Deflections in transverse direction were calculated and analysed. All results are presented in graphical form and discussed. The finite element formulation and its analysis were carried out using ANSYS package.
\end{abstract}

ABSTRAK: Terdapat pelbagai teknik analitikal dan numerical untuk kajian tumpuan tegasan dua dimensi di sekeliling lubang-lubang dalam komposit isotropik dan plat pada satah atau keadaan bebanan melintang. Bagaimanapun, maklumat mengenai kaedah analisis tiga dimensi untuk faktor ketumpatan tegasan (SCF) sekitar lubang dalam komposit isotropik dan plat pada keadaan bebanan melintang adalah terhad. Kertas ini menekankan kesan orientasi gentian $(\theta)$ pada faktor tumpuan tegasan dalam komposit plat bergentian dengan lubang berpusat di bawah keadaan bebanan melintang. Kajian ini dilkukan untuk cantilever plat komposit bergentian. Kesan ketebalan terhadap kelebaran plat (T/A) dan diameter terhadap kelebaran komposit (D/A) dengan SCF pada orientasi gentian berbeza telah dikaji. Plat komposit bagi empat bahan komposit berbeza telah diambilkira bagi kesemua analisis untuk mendapatkan kesensitifan SCF dengan konstan elastic. Defleksi pada arah melintang telah dikira dan dianalisa. Kesemua keputusan telah disembahkan secara grafik dan dibincang. Fomulasi unsur finit dan analisis telah dilaksanakan menggunakan pakej ANSYS.

KEYWORDS: finite element method; stress concentration factor; composites; transverse loading; deflection; elastic constants 


\section{INTRODUCTION}

Fibrous composite plates with central circular hole are finding a wide range of applications in structural design of aerospace, marine, automobile, mechanical engineering especially for light weight structures that have stringent stiffness and strength requirements. Accurate knowledge of deflection, stresses and SCF are required for design of such plates with hole. Any abrupt change in geometry of plate under loading give rise to stress concentration, as a result stress distribution is not uniform throughout the cross section. Composite plates fail due to the failure of individual component (fibre or matrix) or their interface. It is well known that the presence of a notch in a stressed member creates highly localized stresses at the root of the notch. Failures such as fatigue crack and plastic deformation frequently occur at the points of stress concentration. Various researchers analyzed different cases of stress concentration in plate with circular holes.

Shastry and Raj [1] have analyzed the effect of fibre orientation for a unidirectional composite laminate with finite element method by assuming a plane stress problem under in plane static loading. Chaudhuri [2] worked on stress concentration around a part through hole weakening a fibrous plate using finite element method. Paul and Rao [3-5] evaluated stress and stress concentration in fibre reinforced composite fibrous plate containing central circular hole and two coaxial holes subjected to transverse load by using finite element method using Lo Christensen Wu higher order bending theory. Xiwu et al. [6] and [7] studied a finite composite plate weakened by elliptical holes under different inplane loading, treated as an anisotropic multiple connected plates, based on the classical plate theory. Using the complex potential method in the plane theory of elasticity of an isotropic body, an analytical solution concerned with stress concentration around an elliptical hole or holes in finite composite fibrous plate was obtained. Ting et al. [8-9] presented the alternative method to study the stress distributions of the multiple circular or multiple elliptical holes with the rhombic pattern in the infinite domain. Ukadgaonker and Rao [10] proposed a general solution for stresses around hole in symmetric laminates under in-plane loading by introducing a general form of mapping function and an arbitrary biaxial loading condition to the boundary conditions, and the basic formulation is extended for multilayered plates. Troyani et al. [11] have determined the in-plane theoretical stress concentration factors for short rectangular plates with centered circular holes subjected to uniform tension using finite element method. Kotousov and Wang [12] have presented analytical solutions for the three dimensional stress distributions around typical stress concentrators in an isotropic plate of arbitrary thickness based on the assumption of a generalized plane strain theory. Toubal et al. [13] studied stress concentration in a circular hole in composite plate. Ukadgaonker and Kakhandki [14] analyzed the stress around an irregular shaped hole for different in-plane loading conditions for an orthotropic fibrous plate. Gruber et al. [15] developed analytical solution methods for the analysis of stress concentration in fibre reinforced multilayered composites with pin loaded holes. She and Guo [16] have analyzed the variation of three dimensional stress concentration factors along the wall of elliptic holes in finite thickness plates of isotropic materials subjected to remote tensile stress using finite element method. Jain and Mittal [17] have analyzed the stress concentration and deflection in isotropic, orthotropic and fibrous composite plates with central circular hole subjected to transverse static loading by using two dimensional finite element methods. Mittal and Jain [18] analyzed the effect of fibre orientation on stress concentration factor in fibrous plate with central circular hole under transverse static loading by using two dimension finite element methods. Ghezzo et al. [19] performed a numerical and experimental analysis of the interaction between two notches in carbon 
fibre laminates. The numerical analysis of the stress distribution in-plane stress assumption and within the fibrous plate theory framework has been conducted on two symmetric laminates. Ozben et al. [20] compiled FEM analysis of laminated composite plate with rectangular hole and various elastic modulus under transverse loads. Ozen et al. [21] presented the failure loads of mechanical fastened pinned and bolted composite joints with two serial holes. Tsai-Wu failure criterion was used to predict first failure loads by finite element analysis for the geometrical parameters. Kumar et al. [22] has studied the post buckling strengths of composite laminate with various shaped cut-outs under in plane shear. Rao et al. [23] evaluated the stress around square and rectangular cut-outs in symmetric laminates. It has been analyzed that the maximum stress and its location is mainly influenced by the type of loading.

In view of the above literature review, it can be concluded that the analysis of more cases of stress concentration in composite plates with hole subjected to transverse loadings needs to be further investigated in detail. The present work aims to study the effect of fibre orientation $(\theta)$ on stress concentration factor (SCF) in fibrous composite plates with central circular hole subjected to transverse static loading and study of deflection is carried out. The effect of $T / A$ and $D / A$ ratio where $\mathrm{T}$ is the plate thickness and $\mathrm{A}$ is the plate width and $\mathrm{D}$ is the hole diameter on SCF for normal stresses in X, Y directions $\left(\sigma_{\mathrm{x}}, \sigma_{\mathrm{y}}\right)$, shear stress $\left(\tau_{\mathrm{xy}}\right)$, vonmisses (equivalent) stress $\left(\sigma_{\text {eqv }}\right)$ and deflection in transverse direction $\left(\mathrm{U}_{\mathrm{z}}\right)$ is investigated by using three dimensional finite element analysis in cantilever composite plates with central circular hole. The $\mathrm{U}_{\mathrm{z}}$ for different materials for cantilever plate under transverse loading is compared with deflection in transverse direction in plate without hole $\left(\mathrm{U}_{\mathrm{z}}{ }^{*}\right)$. Results are obtained for four different materials to find out the sensitivity of SCF and deflection on elastic constants also.

\section{FORMULATION OF THE PROBLEM}

The model of fibrous composite plate of dimension $0.2 \mathrm{mX} 0.1 \mathrm{~m}$ with $T$ thickness with a central circular hole of diameter $D$ under uniformly distributed loading of $P(\mathrm{~N})$ in transverse direction (Fig. 1.) is taken for analysis. Three different $T / A$ ratios of $0.01,0.05$ and 0.1 are varied and for each T/A ratio three different $D / A$ ratios of $0.1,0.2$ and 0.5 are varied respectively. Four different composite materials are selected for the analysis. The material properties for the composite materials, selected for analysis are shown in Table 1. Where $\mathrm{E}, \mathrm{G}$, and $\mu$ are modulus of elasticity, modulus of rigidity and poisson's ratio respectively.

Table 1: Material properties of composite materials [24].

\begin{tabular}{|c|c|c|c|c|}
\hline Properties & $\begin{array}{c}\text { E-glass/ } \\
\text { Epoxy } \\
(\mathbf{1})\end{array}$ & $\begin{array}{c}\text { Boron/ } \\
\text { Epoxy } \\
\mathbf{( 2 )}\end{array}$ & $\begin{array}{c}\text { Woven- } \\
\text { Glass/Epoxy } \\
\mathbf{( 3 )}\end{array}$ & $\begin{array}{c}\text { Boron/ } \\
\text { Aluminium } \\
\mathbf{( 4 )}\end{array}$ \\
\hline $\mathrm{E}_{\mathrm{x}}$ & $39 \mathrm{GPa}$ & $201 \mathrm{GPa}$ & $29.7 \mathrm{GPa}$ & $235 \mathrm{GPa}$ \\
\hline $\mathrm{E}_{\mathrm{y}}$ & $8.6 \mathrm{GPa}$ & $21.7 \mathrm{GPa}$ & $29.7 \mathrm{GPa}$ & $137 \mathrm{GPa}$ \\
\hline $\mathrm{E}_{\mathrm{z}}$ & $8.6 \mathrm{GPa}$ & $21.7 \mathrm{GPa}$ & $29.7 \mathrm{GPa}$ & $137 \mathrm{GPa}$ \\
\hline $\mathrm{G}_{\mathrm{xy}}$ & $3.8 \mathrm{GPa}$ & $5.4 \mathrm{GPa}$ & $5.3 \mathrm{GPa}$ & $47 \mathrm{GPa}$ \\
\hline $\mathrm{G}_{\mathrm{yz}}$ & $3.8 \mathrm{GPa}$ & $5.4 \mathrm{GPa}$ & $5.3 \mathrm{GPa}$ & $47 \mathrm{GPa}$ \\
\hline $\mathrm{G}_{\mathrm{zx}}$ & $3.8 \mathrm{GPa}$ & $5.4 \mathrm{GPa}$ & $5.3 \mathrm{GPa}$ & $47 \mathrm{GPa}$ \\
\hline$\mu_{\mathrm{xy}}$ & 0.28 & 0.17 & 0.17 & 0.30 \\
\hline$\mu_{\mathrm{yz}}$ & 0.28 & 0.17 & 0.17 & 0.30 \\
\hline$\mu_{\mathrm{zx}}$ & 0.28 & 0.17 & 0.17 & 0.30 \\
\hline
\end{tabular}


Boundary conditions for plate (b) with all edges cantilever $U_{x}=U_{y}=U_{z}=0$ is selected, Fig. 1.
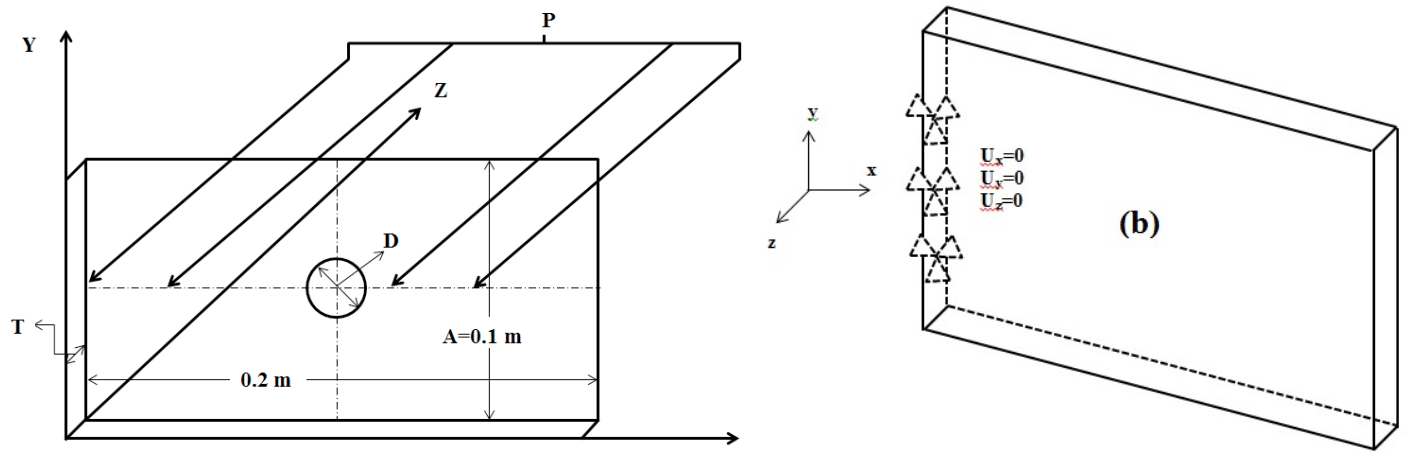

Fig. 1: Cantilever plate with hole under transverse loading.

\section{FINITE ELEMENT ANALYSIS}

The finite element method was chosen for numerical analysis of the model due to its unique capability to analyze structures of complex material behavior. The model was developed using a 3-D solid element specified as, Solid 191 in ANSYS package. The element is defined by 20 nodes having three degrees of freedom per node; a translation in the nodal $\mathrm{x}, \mathrm{y}$ and $\mathrm{z}$ directions, grouping of 60 nodes per element. It is having high stress stiffening capabilities. Typical mesh of the plate using the above element is shown in Fig. 2.

Mapped meshing is used for all models with more elements employed near the hole boundary. Number of checks and convergence tests are made for selection of suitable elements from different available elements, following above the element length is decided as $5 \mathrm{~mm}$. Results were then displayed by using post processor of ANSYS program. The example of the discretized three dimensional finite element models for $D / A=0.2$ and $T / A=0.05$, used in study is shown in Fig. 2.
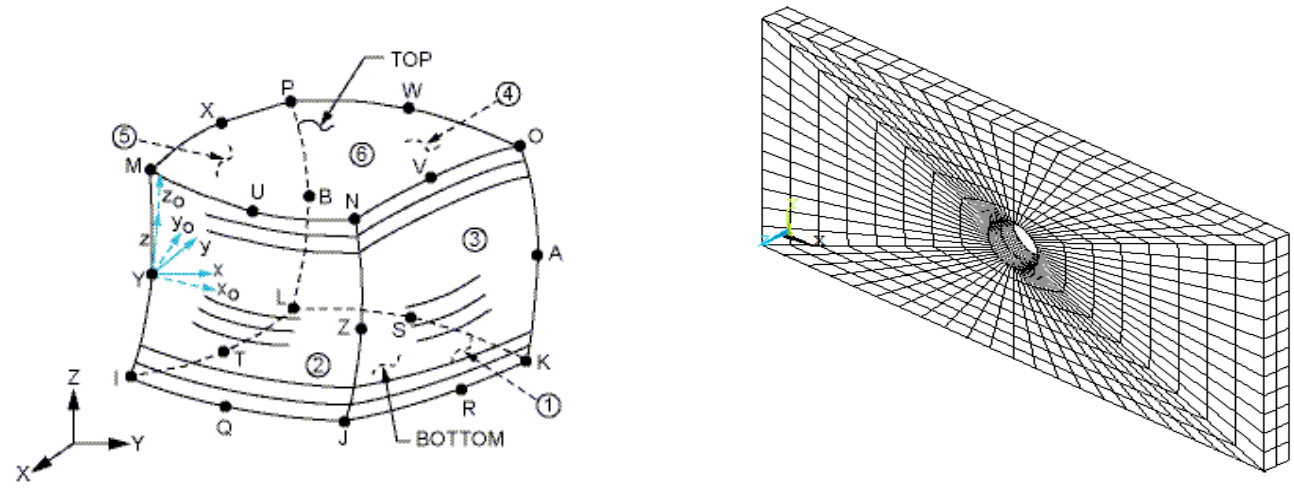

Fig. 2: Element used and generated mesh of the plate.

\section{RESULTS AND DISCUSSION}

Model generated are analysed and results thus obtained for various material combinations are presented in graphs. Results are discussed case by case further. 


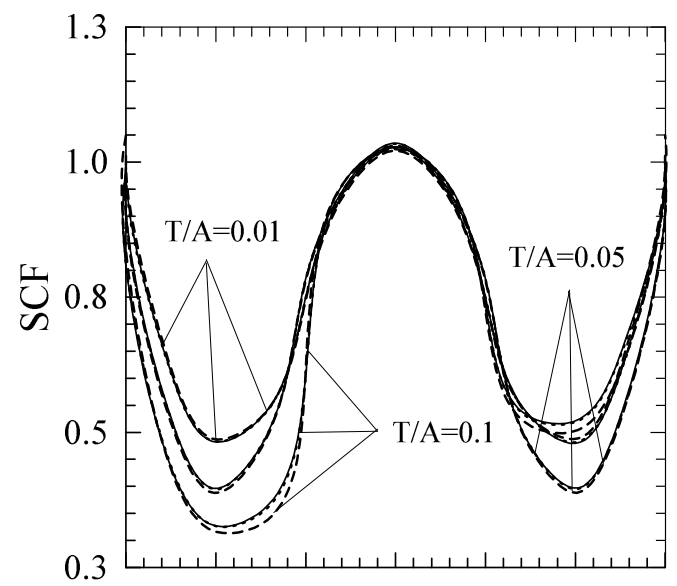

E-glass/Epoxy

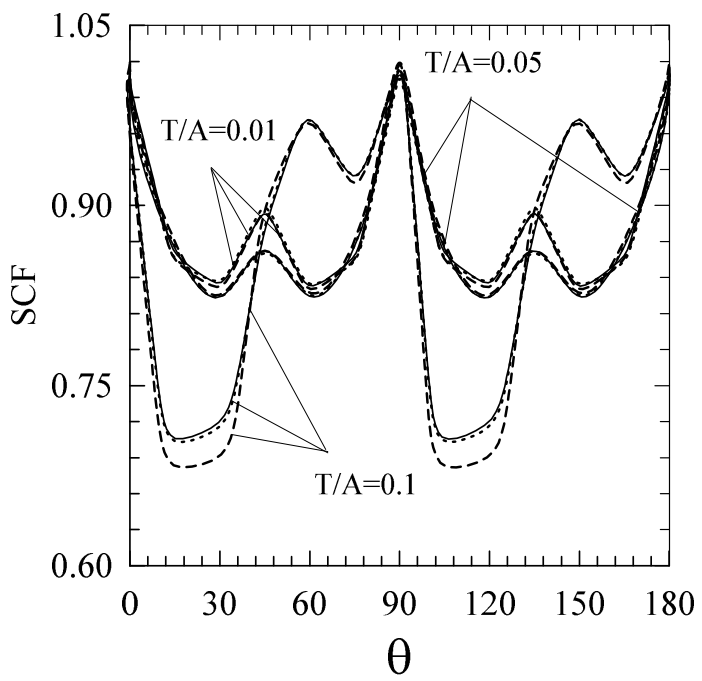

Woven-glass/Epoxy

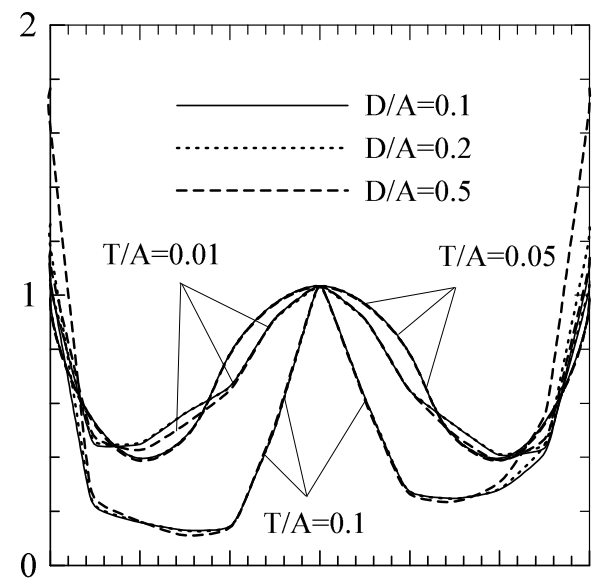

Boron/Epoxy

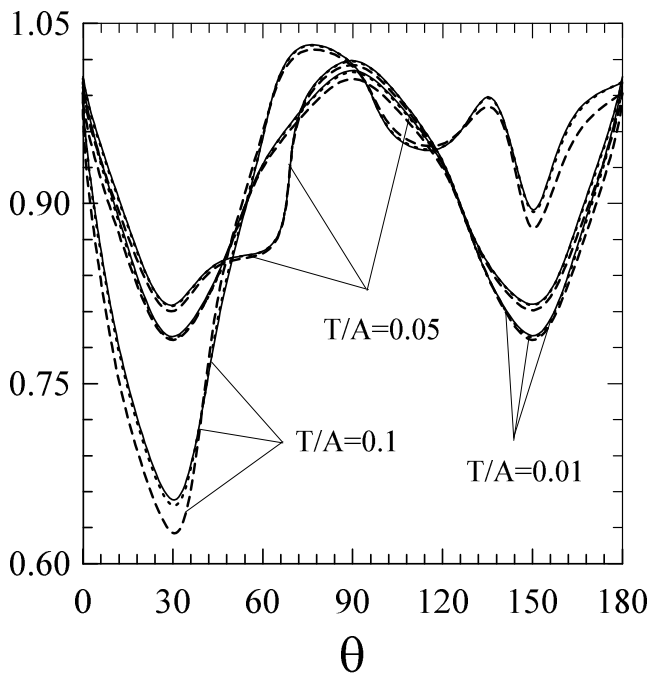

Boron/Alumunium

Fig. 3: Variations of SCF for $\sigma_{\mathrm{x}}$ versus fibre orientation for different materials.

The effect of fibre orientation on SCF for $\sigma_{\mathrm{x}}$ to different $D / A$ and $T / A$ ratios in cantilever fibrous composite plate made of E-glass/Epoxy, boron/epoxy, wovenglass/epoxy and boron/aluminium is shown in Fig. 3. Following observations can be made.

SCF for $\sigma_{\mathrm{x}}$ for cantilever case is not symmetric about any fibre orientation for all materials considered. The effect of T/A ratios plays a substantial role on SCF for $\sigma_{\mathrm{x}}$ for all cases considered, while D/A ratios effect is negligible. Eglass/epoxy composite for the cantilever case shows a non periodic behaviour. From $0^{0}$ to $30^{\circ}$ fibre orientation, SCF for $\sigma_{\mathrm{x}}$ gradually decreases uptill $30^{\circ}$ orientation and from $75^{\circ}$ to $120^{\circ}$ all $T / A$ lines coincide, which shows that effect of T/A and D/A is negligible. Boron/epoxy SCF for $\sigma_{\mathrm{x}}$ decreases from $0^{\circ}$ to $15^{\circ}$ orientation and attaining maximum values at $0^{\circ}$ and $180^{\circ}$ fibre orientation. The minimum value is obtained for $T / A=0.1$ ratios and at $60^{\circ}$ orientation of fibre. Wovenglass/epoxy shows very less variation for SCF of $\sigma_{\mathrm{x}}$ for all orientations with respect to $D / A$ and T/A ratios as compared to simply supported case. Boron/aluminium almost neglected the effect of variation of $T / A$, and shows a very small changes in SCF for 
different fibre orientation. Maximum SCF for $\sigma_{\mathrm{x}}$ are 1.77 and 1.03 is obtained for boron/epoxy and wovenglass/epoxy for $D / A=0.5$ and $T / A=0.1$ at $0^{\circ}$ and $180^{\circ}$ orientation. Again for boron/aluminium maximum SCF of 1.02 value is obtained for $T / A=0.1$ and $D / A=0.5$ at $0^{\circ}$ and $180^{\circ}$ orientation and for eglass/epoxy maximum SCF value of 1.00 is achieved for $T / A=0.01$ and $D / A=0.1$ at again $0^{0}$ and $180^{\circ}$ fibre orientation. Minimum values of SCF for $\sigma_{\mathrm{x}}$ are 0.48, 0.11, 0.68 and 0.65 is obtained for E-glass/Epoxy, Boron/Epoxy, Woven-glass/Epoxy and Boron/Aluminium for $T / A=0.1$ and $D / A=0.1$ and at $0^{\circ}, 45^{\circ}, 15^{\circ}$ and $30^{\circ}$ fibre orientation.
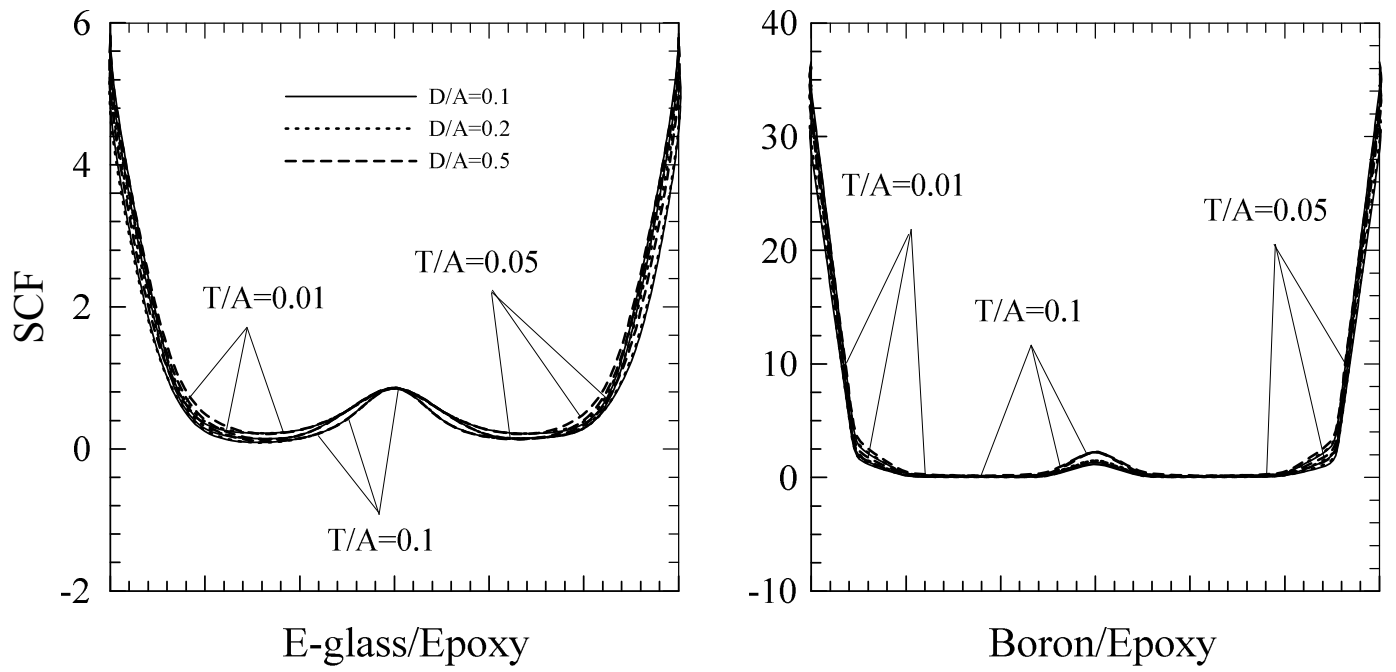

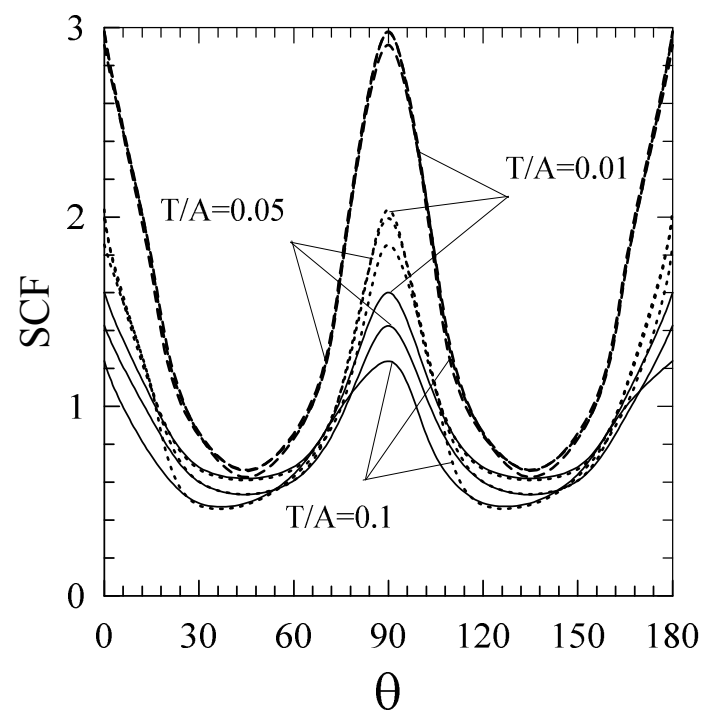

Woven-glass/Epoxy

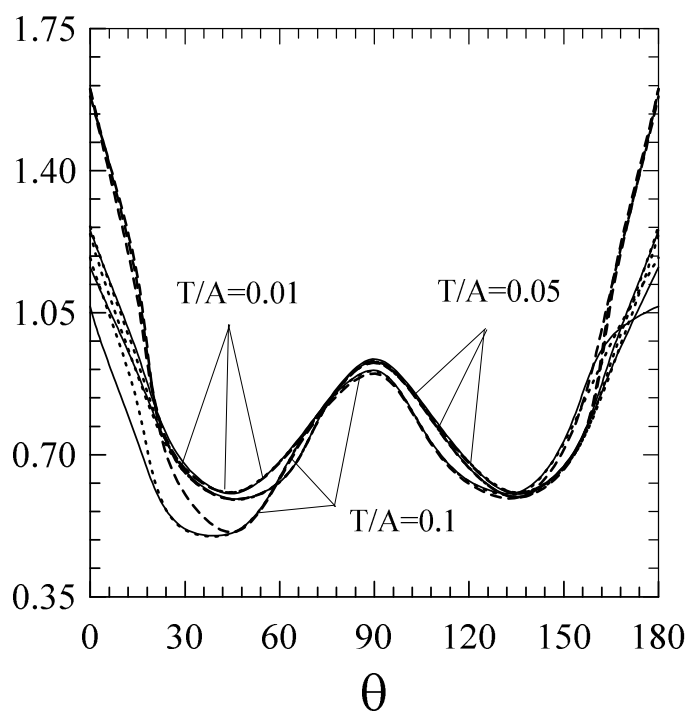

Boron/Alumunium

Fig. 4: Variations of SCF for $\sigma_{\mathrm{y}}$ versus fibre orientation for different materials.

The effect of fibre orientation on SCF for $\sigma_{\mathrm{y}}$ to different $D / A$ and $T / A$ ratios in cantilever fibrous composite plate made of E-glass/Epoxy, boron/epoxy, wovenglass/epoxy and boron/aluminium is shown in Fig. 4. Following observations can be made. 
The effect of T/A and D/A on SCF of $\sigma_{\mathrm{y}}$ is almost negligible for E-glass/Epoxy, and Boron/Epoxy, whereas slight effect of both the ratios can be observed over Wovenglass/Epoxy and Boron/Aluminium. SCF for $\sigma_{\mathrm{y}}$ continously decreases with increase in orientation from $0^{0}$ to $45^{\circ}$ and attaining a maximum value at $0^{\circ}$ and $180^{\circ}$ fibre orientation for E-glass/Epoxy, Boron/Epoxy and Boron/Aluminium. Woven-glass/Epoxy also follows the similar trend, but achieving its maximum value at $0^{\circ}, 90^{\circ}$ and $180^{\circ}$ fibre orientation. Maximum values of SCF for $\sigma_{\mathrm{y}}$ are 6.00, 36.59 and 1.60 are obtained for E-glass/Epoxy, Boron/Epoxy and Boron/Aluminium fibrous composite plate respectively for $T / A=0.01$ and $D / A=0.1$, Whereas for woven-glass/epoxy maximum $2.98 \mathrm{SCF}$ for $\sigma_{\mathrm{y}}$ is attained for $D / A=0.5$ and $T / A=0.01$ at $0^{\circ}$ and $180^{\circ}$ fibre orientation. Minimum value of SCF for $\sigma_{\mathrm{y}}$ are 0.22 and 0.18 is obtained for E-glass/Epoxy and Boron/Epoxy composite plate for $T / A=0.01$ and $D / A=0.1$ at $0^{\circ}$ and $180^{\circ}$ fibre orientation, whereas for woven-glass/epoxy and boron/alimunium maximum SCF value of 0.48 and 0.51 is obtained for $T / A=0.1$ and $D / A=0.2$ at $45^{0}$ fibre orientation.

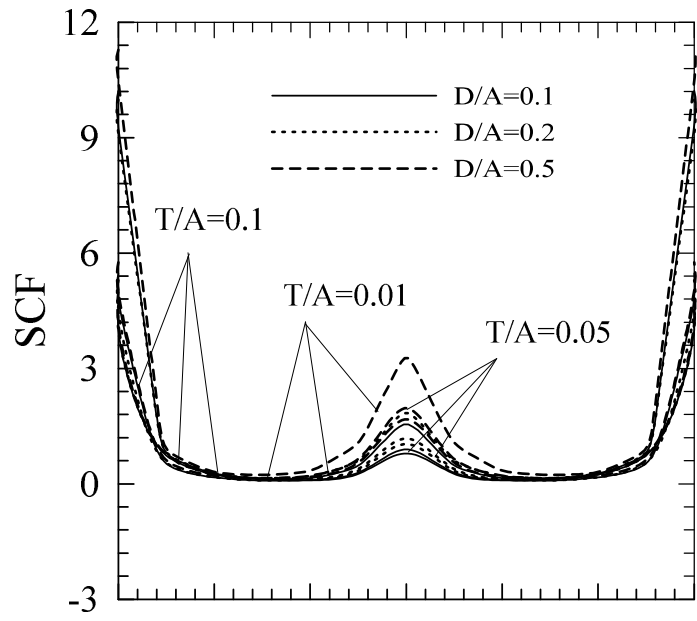

E-glass/Epoxy

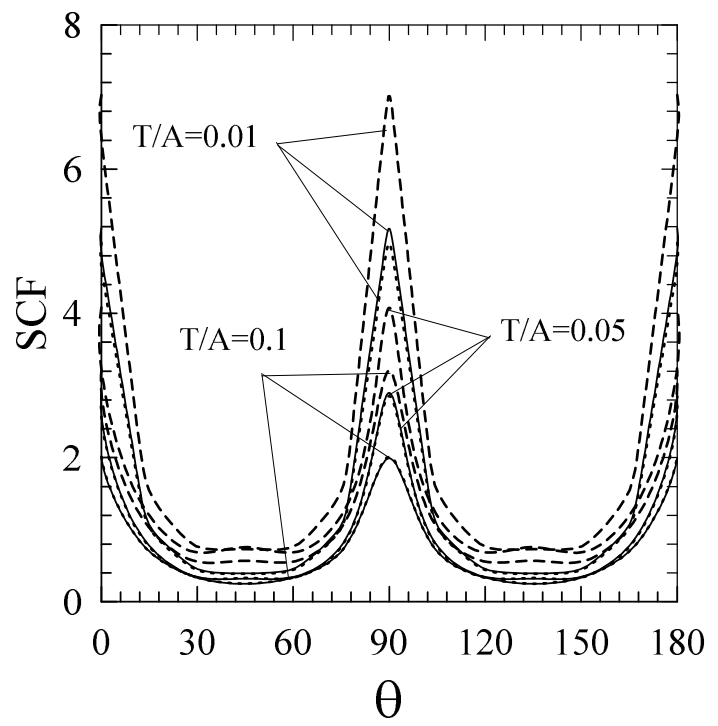

Woven-glass/Epoxy

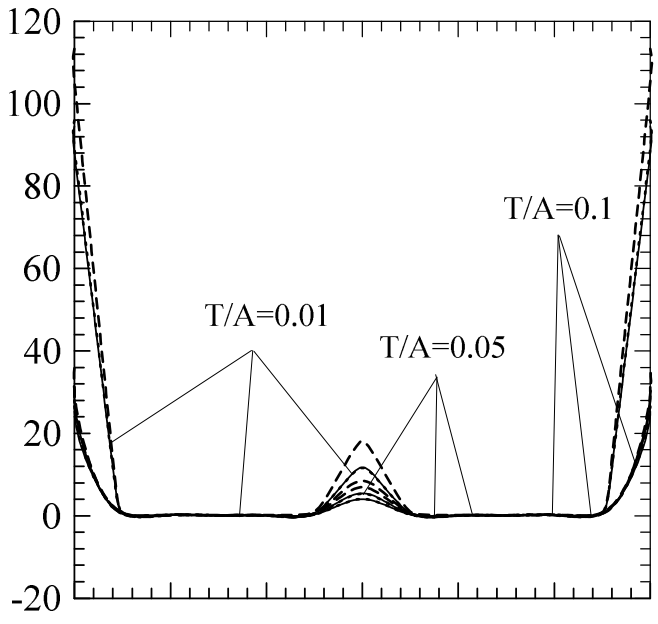

Boron/Epoxy

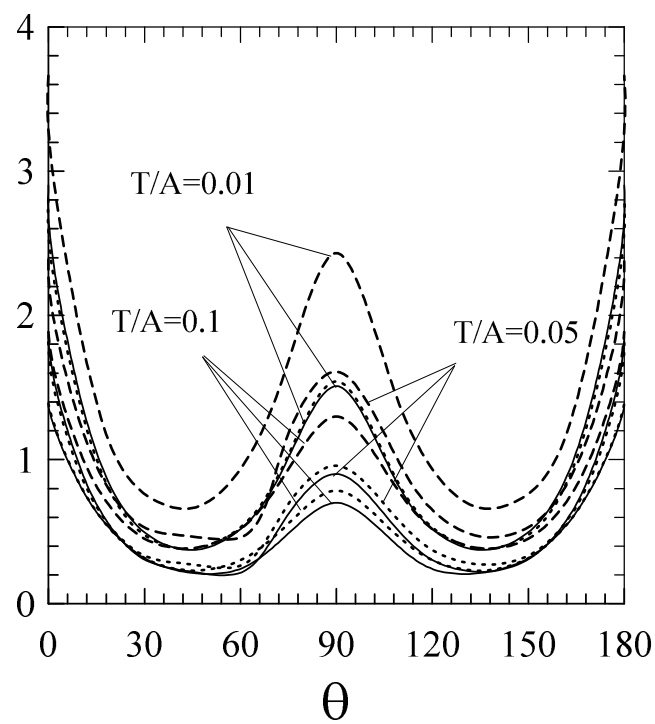

Boron/Alumunium

Fig. 5: Variations of SCF for $\tau_{x y}$ versus fibre orientation for different materials. 
The effect of fibre orientation on SCF for $\tau_{x y}$ to different $D / A$ and $T / A$ ratios in cantilever fibrous composite plate made of E-glass/Epoxy, boron/epoxy, wovenglass/epoxy and boron/aluminium is shown in Fig. 5. Following observations can be made.

The effect of T/A is prominent for SCF of $\tau_{x y}$ of in E-glass/Epoxy and Boron/Epoxy, whereas $D / A$ ratio has very negligible influence on $\mathrm{SCF}$ of the materials. Significant effect of both the ratios can be encountered for Woven-glass/Epoxy and Boron/Aluminium. Maximum value of SCF for $\tau_{\mathrm{xy}}$ are 11.29, 113.26, 7.02 and 3.66 are obtained for Eglass/Epoxy, Boron/Epoxy, Woven-glass/Epoxy and Boron/Aluminium fibrous composite plate respectively for $T / A=0.01$ and $D / A=0.5$ at $0^{\circ}$ and $180^{\circ}$ fibre orientation. Minimum value of SCF for $\tau_{\mathrm{xy}}$ are $0.17,0.06$ and 0.22 is obtained is obtained for E-glass/Epoxy, Boron/Epoxy and Boron/Aluminium fibrous composite plate respectively for $T / A=0.05$ and $D / A=0.1$ at $0^{\circ}$ and $180^{\circ}$ fibre orientation, whereas Woven-glass/Epoxy achieves its minimum value of SCF as 0.25 for $T / A=0.1$ and $D / A=0.1$ at $45^{\circ}$ fibre orientation.
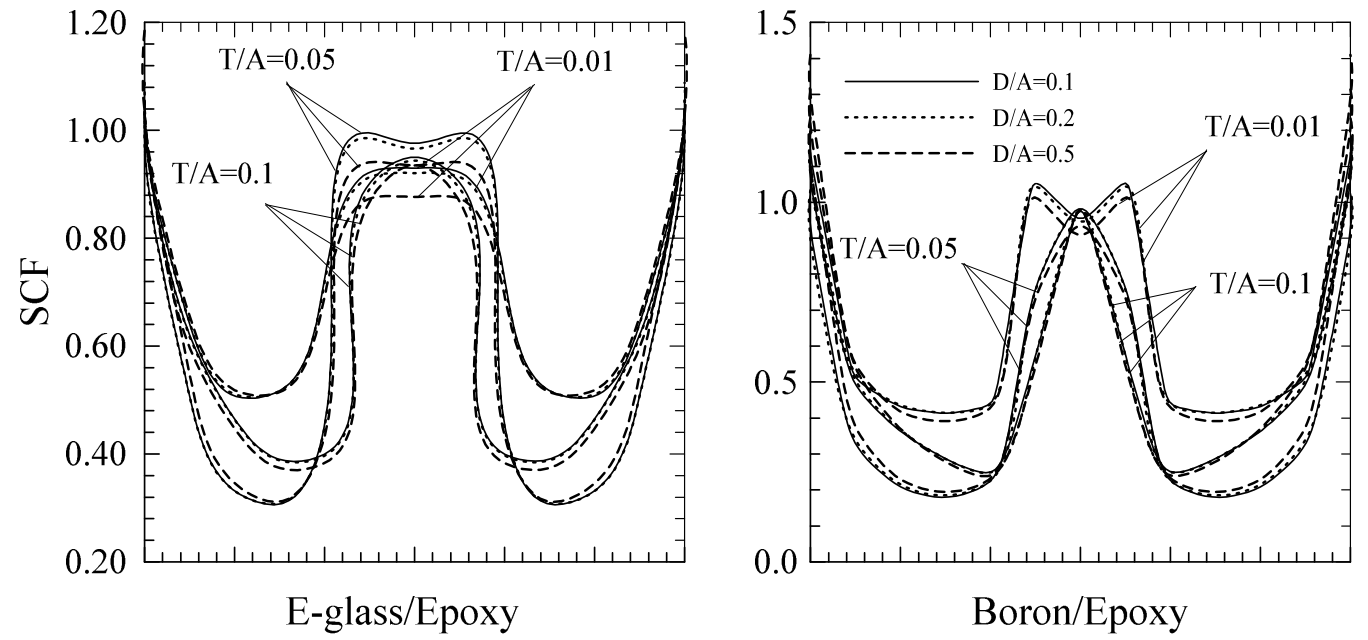

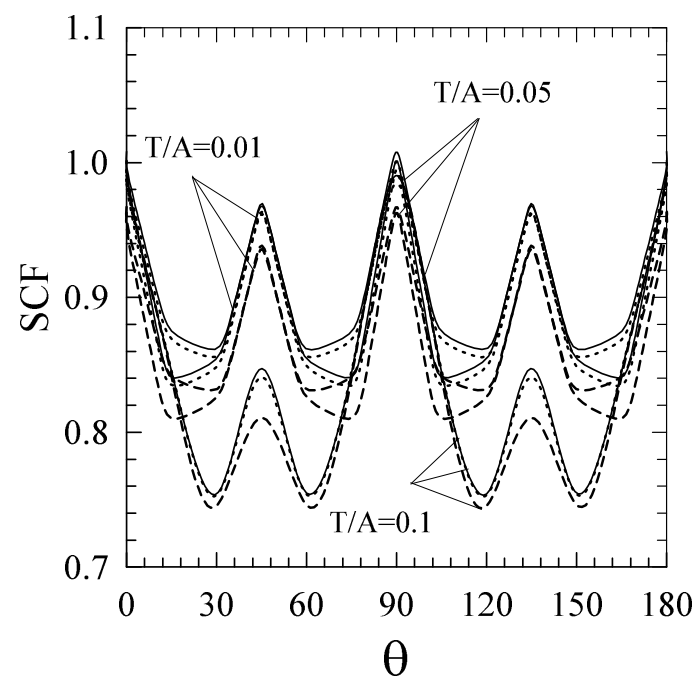

Woven-glass/Epoxy

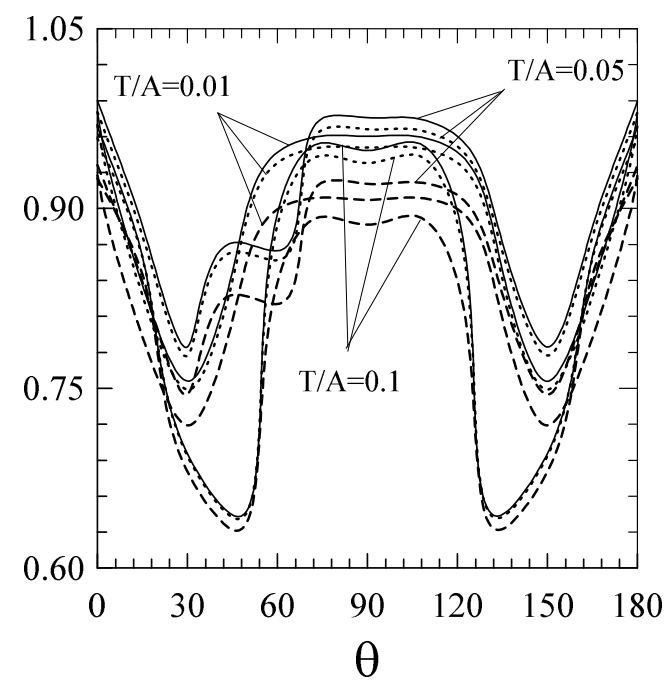

Boron/Alumunium

Fig. 6: Variations of SCF for $\sigma_{\text {eqv }}$ versus fibre orientation for different materials. 
The effect of fibre orientation on SCF for $\sigma_{\text {eqv }}$ to different $D / A$ and $T / A$ ratios in cantilever fibrous composite plate made of E-glass/Epoxy, boron/epoxy, wovenglass/epoxy and boron/aluminium are shown in Fig. 6. Following observations can be made.

$D / A$ ratio effect on all the materials for SCF for $\sigma_{\text {eqv }}$ is almost negligible, whereas effect of $T / A$ ratios on SCF is significant for all composite materials considered. SCF for $\sigma_{\text {eqv }}$ is seen continously decrease on increasing fibre orientation from $0^{0}$ to $45^{\circ}$ and then gradually increase from $45^{\circ}$ to $90^{\circ}$ orientation attaining maximum at $0^{\circ}$ and $180^{\circ}$ orientation for all materials considered. It is to note that maximum SCF of $\sigma_{\text {eqv }}$ are 1.19 and 1.41 are obtained for E-glass/Epoxy and Boron/Epoxy respectively for $T / A=0.01$ and $D / A=0.5$ at $0^{0}$ and $180^{\circ}$ fibre orientation, whereas for Woven-glass/Epoxy and Boron/Aluminium maximum SCF are 1.00 and 0.99 for $T / A=0.05$ and $D / A=0.1$ at same fibre orientation. Minimum value of SCF for $\sigma_{\text {eqv }}$ are 0.31 and 0.18 is obtained for E-glass/Epoxy and Boron/Epoxy respectively for $T / A=0.05$ and $D / A=0.1$ at orientation of $45^{\circ}$, whereas for Woven-glass/Epoxy it is 0.71 for $T / A=0.05$ and $D / A=0.5$ and $0.63 \mathrm{SCF}$ for Boron/Aluminium for $T / A=0.1$ and $D / A=0.5$ at $45^{\circ}$ fibre orientation.
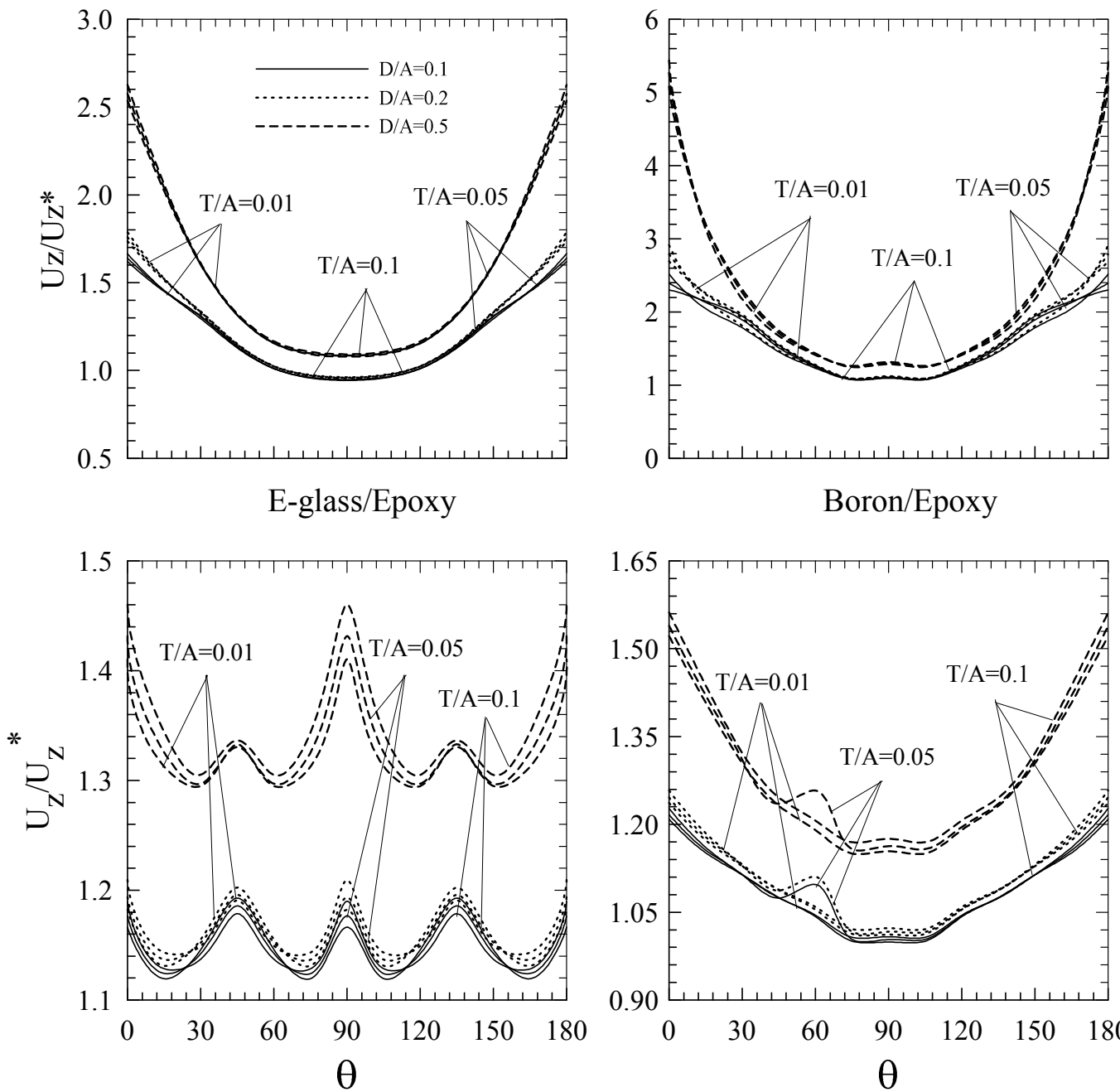

Woven-glass/Epoxy

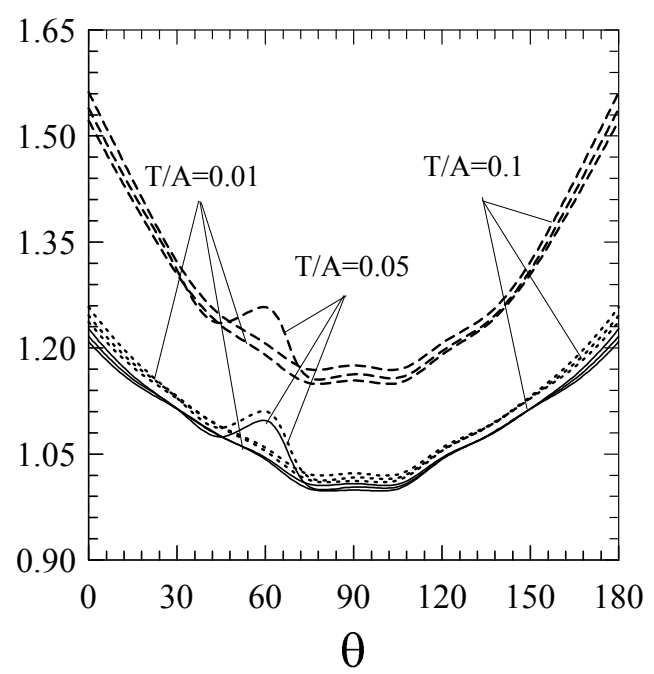

Boron/Alumunium

Fig. 7: Variations of $U_{z} / U_{z}{ }^{*}$ versus fibre orientation for different materials. 
The effect of fibre orientation on $\mathrm{U}_{\mathrm{z}} / \mathrm{U}_{\mathrm{z}}{ }^{*}$ to different $D / A$ and $T / A$ ratios in cantilever fibrous composite plate made of E-glass/Epoxy, Boron/Epoxy, Woven-glass/Epoxy and Boron/Aluminium is shown in Fig. 7. Following observations can be made.

The influence of $T / A$ and $D / A$ is significant for $\mathrm{U}_{\mathrm{z}} / \mathrm{U}_{\mathrm{z}}{ }^{*}$ for all cases of materials under different fibre orientation. It can be noticed that $\mathrm{U}_{\mathrm{z}} / \mathrm{U}_{\mathrm{z}}{ }^{*}$ is continously decrease with increase of orientation of fibre from $0^{\circ}$ to $90^{\circ}$, and gradually increase from $90^{\circ}$ to $180^{\circ}$ attaining a maximum value at $0^{\circ}$ and $180^{\circ}$ orientation for all materials considered except Woven-glass/Epoxy following a wavy pattern with continous decrease of $\mathrm{U}_{\mathrm{z}} / \mathrm{U}_{\mathrm{z}}{ }^{*}$ from $0^{0}$ to $45^{\circ}$ and then gradual increment from $45^{\circ}$ to $90^{\circ}$ orientation obtaining maximum value at $0^{0}, 90^{\circ}$ and $180^{\circ}$ fibre orientation. $\mathrm{U}_{\mathrm{z}} / \mathrm{U}_{\mathrm{z}}{ }^{*}$ attains its maximum value of $2.63,5.44$ and 1.56 for E-glass/Epoxy, Boron/Epoxy and Boron/Aluminium for $T / A=0.1$ and $D / A=0.5$ at $90^{\circ}$ fibre orientation. Woven-glass/epoxy following a peoridic pattern shows its maximum value as 1.46 again for $T / A=0.1$ and $D / A=0.5$ at $0^{\circ}, 90^{\circ}$ and $180^{\circ}$ fibre orientation. Minimum value of $\mathrm{U}_{\mathrm{z}} / \mathrm{U}_{\mathrm{z}}{ }^{*}$ are 0.94, 1.10 and 1.00 for E-glass/Epoxy, Boron/Epoxy and Boron/Aluminium for $T / A=0.01$ and $D / A=0.1$ at $90^{\circ}$ orientation, whereas for Wovenglass/Epoxy the minimum value reaches to be 1.12 for again $T / A=0.01$ and $D / A=0.1$ but at $15^{\circ}, 75^{\circ}$ and $165^{\circ}$ fibre orientation.

\section{CONCLUSION}

a) Higher $E_{x} / E_{y} \& E_{x} / G_{x y}$ ratios increases the value of SCF for $\sigma_{x}$ of E-glass/Epoxy \& Boron /Epoxy as they are having highest of these values as compared to Wovenglass/Epoxy \& Boron/Aluminium.

b) SCF for $\sigma_{\mathrm{x}}$ is maximum near the fixed end of the plate, $\sigma_{\mathrm{y}}$ is maximum at the hole boundary towards the longitudnal (x) direction of the plate. $\sigma_{\mathrm{xy}}$ is maximum again at fixed end of the plate, but at their extreme corners only. $\sigma_{\text {eqv }}$ is showing its maximum value at fixed end of the plate through out its thickness. $U_{z}$ shows its maximum value through out its edge over the fixed end, expanding quarter half of the plate.

c) The SCF for $\sigma_{\mathrm{x}} \& \mathrm{U}_{\mathrm{z}}$ shows its maximum value at $0^{0}$ orientation of fiber. The SCF for $\sigma_{\mathrm{y}}$ and the materials having higher $\mathrm{E}_{\mathrm{x}} / \mathrm{E}_{\mathrm{y}} \& \mathrm{E}_{\mathrm{x}} / \mathrm{G}_{\mathrm{xy}}$ ratios have almost discarded the effect of both $D / A \& T / A$ ratios. Again for materials considered with lesser $\mathrm{E}_{\mathrm{x}} / \mathrm{E}_{\mathrm{y}}$ $\& \mathrm{E}_{\mathrm{x}} / \mathrm{G}_{\mathrm{xy}}$ ratios shows significant role in variation of $D / A \& T / A$ ratios.

d) The effect of $D / A$ ratio is negligible for the SCF of $\sigma_{x}, \sigma_{y}, \sigma_{x y}$ and $\sigma_{\text {eqv }}$ except for deflection case, only $T / A$ ratios variation can be clearly encountered.

e) SCF for $\sigma_{y}, \sigma_{x y}, \sigma_{\text {eqv }}$ and $\mathrm{U}_{\mathrm{z}}$ is symmetric for $90^{\circ}$ fibre orientation except for $\sigma_{\mathrm{x}}$.

f) SCF values for $\sigma_{\mathrm{x}}$ have reached to 1 and less than 1 for $D / A=0.5$ and all $T / A$ ratios at $30^{\circ}$ fiber orientation.

g) SCF values for $\sigma_{\mathrm{x}}$ reduces with the increase of $T / A$ and $D / A$ ratios.

\section{ACKNOWLEDGEMENT}

The authors acknowledge the authorities of N.I.T, Raipur for permitting the above work to be carried out.

\section{REFERENCES}

[1] B.P. Shastry and G.V. Raj. "Effect of fibre orientation on stress concentration in a unidirectional tensile laminate of finite width with a central circular hole." Fibre Science Technology, 10(1977): 151-4. 
[2] R.A. Chaudhuri. "Stress concentration around a part through hole weakening laminated plate." Computers and Structurcs, 27.5(1987): 601-9.

[3] T.K. Paul and K.M. Rao." Stress analysis in circular holes in FRP laminates under transverse load." Computers and Structures, 33.4 (1989): 929-35.

[4] T.K. Paul and K.M. Rao. "Finite element evaluation of stress concentration factor of thick laminated plates under transverse loading." Computers and Structures, 48.2 (1993):3117.

[5] T.K. Paul and K.M. Rao. "Finite element stress analysis of laminated composite plates containing two circular holes under transverse loading." Computers and Structures, 54(1995): 671-7.

[6] X. Xiwu, S. Liangxin, and F. Xuqi. "Stress concentration of finite composite laminates with elliptical hole." Computers and Structures, 57.1(1995): 29:34.

[7] X. Xiwu, S. Liangxin, and F. Xuqi. "Stress concentration of finite composite laminates weakened by multiple elliptical holes." Intemational Journal of Solids Structures, 32.20(1995): 3001-14.

[8] K. Ting, K.T. Chen and W.S. Yang. "'boundary element alternating method applied to analyze the stress concentration problems of multiple elliptical holes in an infinite domain." Nuclear Engineering and Design, 187(1999): 303-13.

[9] K. Ting, K.T. Chen and W.S. Yang. "Stress analysis of the multiple circular holes with the rhombic amay using alternating method." Intemational Journal of Pressure Vessels and piping, 76(1999): 503-14.

[10] V.G. Ukadgaonker and D.K.N. Rao. "A general solution for stresses around holes in symmetric laminates under in plane loading." Composite Structure,49(2000): 339-54

[11] N. Troyani, C. Gomes and G. Sterlacci. "Theoretical stress concentration factors for short rectangular plates with centered circular holes." Journal of Mechanical Design, ASME, 124(2007): 126-8.

[12] Kotousov and C.H. Wang. "Threedimensional stress constraint in an elastic plate with a notch." International Journal of Solids and Stuctures, 39(2002): 4311-26.

[13] Toubal, M. Karama and B. Lorrain. "Stress concentration in a circular hole in composite plate." Composite Structures, 68(2005): 31-6.

[14] V.G. tlkadgaonker and V. Kakhandki. "Stress analysis for an orthotropic plate with an irregular shaped hole for different in-plane loading conditions-Part 1." Composite Structures, 70(2005): 255-74.

[15] Gruber, W. Hufenbach, L. Kroll, M. Lepper and B. Zhou. "Sress concentration analysis of fibre-reinforced multilayered composites with pin-loaded holes." Composites Science and Technolog, 67(2007): 1439-50.

[16] She and W.Guo. "Threedimensional stress concentrations at elliptic holes in elastic isotropic plates subjected to tensile stress." International Journal of Fatigue, 29(2007): 330-5.

[17] N.K. Jain and N.D. Mittal. "Finite element analysis for stress concentration and deflection in isotropic, orthotropic and laminated composite plates with central circular hole under transverse static loading." Materials Science and Engineering, 498(2008): 115-24.

[18] N.K. Jain and N.D. Mittal. "Effect of fibre orientation on stress concentration factor in a laminate with central circular hole under transverse static loading." Indian Journal of Engineering \& Material Sciences, 15(2008): 452-8.

[19] F. Ghezzo, G. Giannini, F. Cesari and G. Galigiana. "Numerical and experimental analysis of the interaction between two notches in carbon fibre laminates." Composites Science and Technology, 68(2008): 1057-72.

[20] T. Ozben and N. Arslan. "EM analysis of laminated composite plate with rectangular hole and various elastic modulus under transverse loads." Applied Mathematical Modeling, 34(2010): 1746.

[21] M. Ozen and O. Sayman. "Failure loads of mechanical fastened pinned and bolted composite joints with two serial holes." Composites: Part B, 2010.

[22] Kumar and S.B. Singh. "Post buckling strengths of composite laminate with various shaped cutouts under in-plane shear." Composite Structure, 92(2010): 296-7. 
[23] D.K.N. Rao, M.R. Babu, K.R.N. Reddy and D. Sunil. "Stress around square and rectangular cutouts in symmetric laminates." Composite Structures, 19(2010).

[24] I.M. Daniel and O. Ishai. Engineering Mechanics of Composite Materials. New York: Oxford University Press, 1994. 